\title{
Hatay ili Arsuz ilçesi topraklarının besin elementi durumları ve bunların bazı toprak özellikleri ile ilişkileri
}

Nutrient status of Arsuz district soils of Hatay province and their relations with some soil properties

\author{
Mehmet YALÇIN ${ }^{1 / D}$, Kerim Mesut ÇiMRiN ${ }^{1}$
}

${ }^{1}$ Hatay Mustafa Kemal Üniversitesi, Ziraat Fakültesi, Toprak ve Bitki Besleme Bölümü, Antakya-Hatay, Türkiye.

MAKALE BILGISI / ARTICLE INFO

Makale tarihçesi / Article history:

DOI: $10.37908 /$ mkutbd.940809

Geliş tarihi /Received:21.05.2021

Kabul tarihi/Accepted:30.07.2021

\section{Keywords:}

Arsuz district, soil properties, fertility.

\footnotetext{
Corresponding author: Mehmet YALÇIN

$\bowtie:$ myalcin@mku.edu.tr
}

\author{
ÖZET / A BSTRACT
}

Aims: It was aimed to determine some the macro and micro nutrient concentration of the soils of Arsuz district of Hatay province and to evaluate the fertility status of the soils of the region by revealing their relationship with some soil properties.

Methods and Results: In the study, a total of 70 surface soil samples were taken from a depth of $0-30 \mathrm{~cm}$ and 70 different points, representing the lands of Hatay-Arsuz district. According to the results of the research, total $\mathrm{N}$ concentration of soils were determined between $0.03 \%$ and $1.02 \%$, available $P$ was determined between 0.14 and $1.82 \mathrm{mg} \mathrm{kg}^{-1}$; exchangeable $\mathrm{K}$ was between 102 and $523 \mathrm{mg} \mathrm{kg}^{-1}$; exchangeable Ca was found to be between 2478 and $5472 \mathrm{mg} \mathrm{kg}^{-1}$; exchangeable $\mathrm{Mg}$ was determined between 310 and $1693 \mathrm{mg} \mathrm{kg}^{-1}$; obtainable $\mathrm{Cu}$ was determined between 0.65 and $4.77 \mathrm{mg} \mathrm{kg}^{-1}$; Fe between 1.65 and $18.72 \mathrm{mg} \mathrm{kg}^{-1}$; $\mathrm{Mn}$ between 1.38 and $22.47 \mathrm{mg} \mathrm{kg}^{-1}$ and $\mathrm{Zn}$ between 0.15 and $1.71 \mathrm{mg} \mathrm{kg}^{-1} .2 .86 \%$ of the land of Arsuz district are very low in N, $12.86 \%$ of it is low, $20.00 \%$ of it is medium, $30.00 \%$ of it is high, and $34.28 \%$ of the land of the distirct is very high.

Conclusions A very low level of phosphorus was determined in terms of phosphorus content in all the soils of the study area. In terms of exchangeable potassium content of soils, $47.15 \%$ was determined to be low, $25.71 \%$ medium, $17.14 \%$ high and $10.00 \%$ very high. While deficiencies in terms of available $\mathrm{Zn}$ and $\mathrm{Mn}$ were determined in most of the soils, no deficiencies were found in terms of total $\mathrm{N}$, available $\mathrm{Ca}, \mathrm{Mg}$, $\mathrm{Cu}, \mathrm{Fe}$ and their contents. It was found in the study that there were significant negative correlations between available $\mathrm{P}$ and CEC contents of soils, available $\mathrm{Mg}$ and sand contents, available $\mathrm{Cu}$ and $\mathrm{Fe}$ and $\mathrm{pH}$ and sand contents, available $\mathrm{Mn}$ and $\mathrm{pH}$ and lime contents, and available $\mathrm{Zn}$ and $\mathrm{pH}$ values. It was also determined that there were positive significant relationships between the available $P$ and silt contents of soils, exchangeable $\mathrm{K}$ and salt and clay contents, $\mathrm{Ca}$ and lime and CEC values, available $\mathrm{Mg}$ and $\mathrm{pH}$, salt and clay contents, obtainable $\mathrm{Mn}$ and $\mathrm{Zn}$ and sand and CEC values.

Significance and Impact of the Study: Considering the examined fertility conditions of the soils of Arsuz district of Hatay province, it is revealed that the deficiencies of the available $P, \mathrm{Zn}$ and $\mathrm{Mn}$ must be supported by fertilization. 


\section{GíRiş}

Toprak, bitkilerin yaşamsal döngülerinin devam ettirebilmeleri için ihtiyaç duydukları besin elementlerini biriktirdikleri, mikroorganizmaların faaliyetlerini sağlayabildiği, canlı yaşamın hayatının devamlılığını engelleyen zararlı toksisitelerin olumsuzluklarını azaltan ve doğal çevreye zararlı kirleticileri süzerek dönüşümlerini sonlandıran dinamik bir varlıktır (Yeter ve Yalçın, 2020). Son yıllarda nüfusun artması ile yükselen daha kaliteli ürün ihtiyacının oluşturduğu baskı ve bununla birlikte zaman içerisinde ilerleyen sanayileşme, tarım amaçlı kullanılan toprakların farklı düşüncelerle kullanılması, verimli alanların zamanla azalmasına neden olmaktadır. Tarım topraklarında bitkilerin gelişim dönemleri boyunca döngü içerisinde kökleri vasıtasıyla önemli miktarda besin elementlerini kaldırması, dengesiz gübreleme, toprakların verimliliklerini zaman içerisinde azaltmaktadır. Tarımsal alanların azalan verimliliklerinin devamlılığı sağlayabilmek için toprak parametrelerinin periyodik olarak analizlerle belirlenmesi, bitkilerin besin elementleri ihtiyaç ve yeterliliklerinin ölçülmesi verimlilikte büyük önem arz etmektedir (Karaduman ve Çimrin, (2016). Geçmişten günümüze birçok tarım topağının verim durumlarının belirlenmesi ve muhtemel besin elementleri eksikliği ya da fazlalığı nedeniyle ortaya çıkan sorunların önceden bilinmesi amacı ile çalışmalar yürütülmüştür. Örnek olarak, Yalçın ve ark., (2018) Hatay, Reyhanlı çayır-mera topraklarının besin maddesi durumlarını belirlemek amacı ile iki farklı derinlikten 80 adet toprak üzerinde çalışmışlardır. Çalışma sonucuna göre; toprakların ortalama azot içeriklerini $(\mathrm{N}) \% 0.24$, alınabilir fosfor içeriklerini (P) 1.40, değişebilir potasyum (K) 416.6, kalsiyum (Ca) $808.95 \mathrm{mg} \mathrm{kg}^{-1}$ olarak belirlenirken, bakır (Cu) 2.99, demir (Fe) 18.5, mangan (Mn) 33.0, çinko ( $\mathrm{Zn}$ ) $1.57 \mathrm{mg} \mathrm{kg}^{-1}$ olarak belirlenmiştir. Sonuç olarak araştırıcılar, toprakların çoğunluğunda $\mathrm{P}$ ve $\mathrm{Zn}$, çok daha az kısmında ise $K$, ve Ca yönünden noksanlık, bildirilirken, bitki tarafından alınabilir $\mathrm{Cu}$, Fe ve $\mathrm{Mn}$ içerikleri açısından bir sorun rapor edilmemiştir. Çalışmada, toprakların azot ile tuz, yarayışlı $\mathrm{P}$ ile kil ve $\mathrm{pH}, \mathrm{K}$ ile kum, Cu ve Fe ile $\mathrm{pH}$, kum ve $\mathrm{Mn}$ ile $\mathrm{pH}$, Ca ile kum içerikleri arasında önemli negatif ilişkiler saptanmıştır. Ayrıca, toprakların organik madde ile KDK, $\mathrm{P}$ ile ile tuz, organik madde ve KDK içerikleri arasında önemli pozitif ilişkiler belirlenmiştir. Doğan ve Erdal (2018) Burdur ili tahıl yetiştirilen toprakların verimlilik durumlarını belirlemişlerdir.
Çalışma sonucuna göre; topraklarının \%80'inin tın, kil ve killi-tınlı olduğu görülmüştür. Toprakların tamamında tuzluluk sorunu bulunmamakta olup, büyük çoğunluğunun kireç içeriklerinin yüksek, hafif alkalin reaksiyonlu ve organik madde bakımından yetersiz olduğu görülmüştür. Tahıl topraklarının genelinde makro elementler ve bakırın yeterli olduğu, buna karşılık \% 40'ında demir \% 89'unda mangan ve \% 56'sında çinkonun noksan olduğu saptanmıştır. Gaziantep ili kiraz (Prunus avium L.) bahçelerinin ( $\mathrm{N}, \mathrm{P}, \mathrm{K}, \mathrm{Fe}, \mathrm{Zn}, \mathrm{Cu}$ ve $\mathrm{Mn}$ ) beslenme durumları ve toprakların bazı fiziksel ve kimyasal özelliklerini belirlemek amacıyla yürüttüğü bir çalışmada, 20 adet kiraz bahçesinden kış dönemine, bitkiler dinlenme halinde iken toprak örnekleri alınmıştır. Araştırma sonuçlarına göre; bünye yönünden topraklar kiraz yetiştiriciliği için uygun olup, toprakların tamamında tuzluluk sorunu olmadığı ve yüksek kireçli olduğu, bu toprakların \% 80'ninin organik maddece \% $70.0^{\prime}$ inin azot, \%25'inin fosfor, \%35'inin potasyum, $\% 50$ 'sinin çinko bakımından yetersiz olduğu belirlenmiştir (Çimrin, 2018). Eren (2019) Kızıltepe yöresinde buğday tarımı yapılan toprakların bazı verimlilik durumlarını belirlemiştir. Çalışma sonucuna göre; toprakların "Killi-Tın" bünyeye sahip olduğu, tuzluluk probleminin olmadığı, toprakların \% 59.3'ü "nötr" reaksiyonlu, \% 40.7'si ise "hafif alkalin" reaksiyonlu olduğu ve organik madde miktarları ise toprakların \% 67.4'ü "az", \% 32.6'sı ise "orta" seviyede olduğu belirlenmiştir.

Çalışmada Hatay iline bağlı Arsuz ilçesi maydanoz ekilen toprakların bitkinin alabildiği bazı bitki besin maddesi miktarlarının durumlarının saptanması, aynı zamanda bitki besin maddesi içerikleri ile bu toprakların temel özellikleri arasındaki ilişkilerini açığa çıkararak, bölge topraklarının beslenme ve verimliliklerinin belirlenmesi amaçlanmıştır.

\section{MATERYAL ve YÖNTEM}

Hatay ili Arsuz ilçesi maydanoz ekilen alanları temsil edecek şekilde bu alanlarından 70 farklı noktadan, yüzey toprak örneği $(0-30 \mathrm{~cm})$ amacına uyumlu olarak örneklenmiştir (Şekil 1; Çizelge 1). Alınan toprak örnekleri vakit kaybetmeksizin aynı gün laboratuvara taşınmış ve havada kuru toprakları elde etmek için sürekli karıştırılarak gölgede bekletilmiş ve $2 \mathrm{~mm}^{\prime}$ lik elekten geçirilerek saklama kaplarında analizlere kadar bekletilmiştir. 


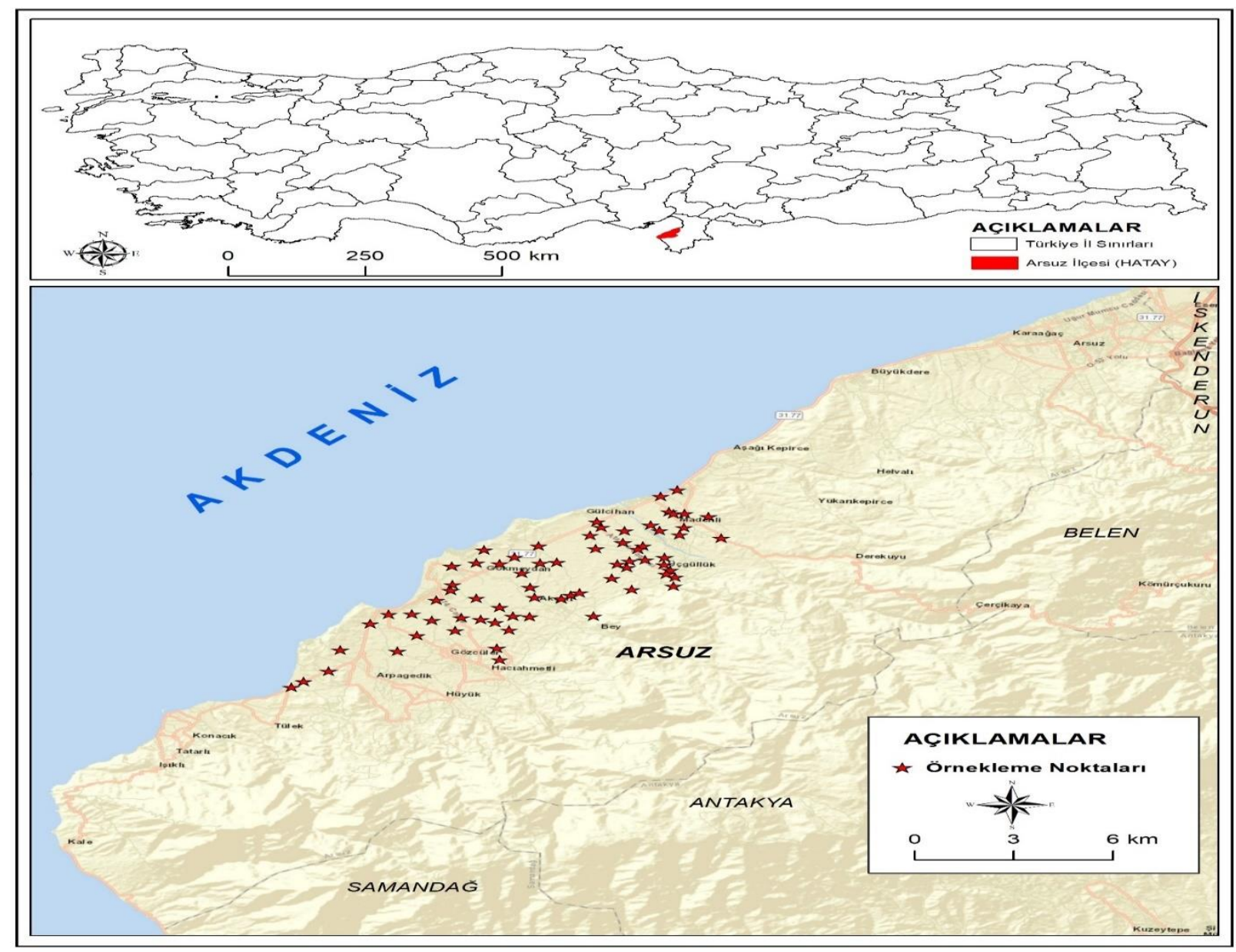

Şekil 1. Çalışma alanı toprak örneklerinin harita üzerinde konumları

Figure 1. Location of the study area soil samples on the map

Toprakların $\mathrm{pH}$ değerleri saturasyon çamuru ekstraktında $\mathrm{pH}$ metre ile toplam çözünebilir tuz içerikleri ise elektriksel iletkenlik aletinde ölçülerek belirlenmiştir (Horneck ve ark., 1989). Toprakların kireç (CaCO3) içerikleri Scheibler kalsimetresi aleti ile dört tekrarlamalı olarak ölçülmüştür (Nelson, 1982). Toprak örneklerinde Bünye hidrometre yöntemi (Bouyoucos, 1952), organik madde modifiye edilmiş Walkley-Black yöntemiyle belirlenmiştir (Nelson ve Sommers; 1982).

Katyon değişim kapasitesi, sodyum asetat (1N pH: 8.2) ekstraksiyon yöntemi ile (Rhoades, 1982). Toprakların toplam azot (N) içerikleri Kjeldahl yöntemine göre (Bremner ve Mulvaney 1982); yarayışlı fosfor (P) içerikleri (Olsen ve Sommers 1982) tarafından bildirildiği şekilde $0.5 \mathrm{M} \mathrm{NaHCO} 3(\mathrm{pH}=8.5)$ ile ekstrakte edilerek çözeltiye geçen $\mathrm{P}$, mavi renk yöntemine göre, alınabilir potasyum (K), kalsiyum (Ca) ve magnezyum (Mg) Anonymous, (1992)'un bildirildiği gibi $1.0 \mathrm{~N}$ nötr amonyum asetat ile ekstrakte edilerek yapılmıștır. Toprakların yarayışlı bakır (Cu), demir (Fe), mangan (Mn) ve çinko (Zn) Lindsay ve Norwell (1978)'e göre $0.005 \mathrm{M}$ DTPA+0.01 M CaCl2+0.1 M TEA (pH 7.3) ekstraktında belirlenmiştir. Çalışmada bitki besin maddeleri ve toprak temel karakteristikleri arasındaki korelasyonlar SPSS 17 programında yapılmıştır (Düzgüneş ve ark., 1987). 
Çizelge 1. Toprak örneklerinin alındığı yerler

Table 1. Soil sampling areas

\begin{tabular}{|c|c|c|c|c|c|}
\hline $\begin{array}{c}\text { Örnek } \\
\text { No }\end{array}$ & Köyler & $\begin{array}{l}\text { GPS ile N/E } \\
\text { Koordinatları }\end{array}$ & Örnek No & Köyler & GPS ile N/E Koordinatları \\
\hline 1 & Madenli 1 & $(36.4718-35.9798)$ & 36 & Akçalı 8 & $(36.4113-35.9595)$ \\
\hline 2 & Madenli 2 & $(36.4751-35.9852)$ & 37 & Akçalı 9 & $(36.4202-35.9392)$ \\
\hline 3 & Madenli 3 & $(36.4641-35.9828)$ & 38 & Akçalı 10 & $(36.4251-35.9376)$ \\
\hline 4 & Madenli 4 & (36.4515 - 36.0009) & 39 & Akçalı 11 & $(36.4374-35.9404)$ \\
\hline 5 & Madenli 5 & $(36.4620-35.9962)$ & 40 & Akçalı 12 & $(36.4459-35.9396)$ \\
\hline 6 & Madenli 6 & (36.4564 - 35.9883) & 41 & Akçalı 13 & $(36.4401-35.9318)$ \\
\hline 7 & Madenli 7 & $(36.4631-35.9845)$ & 42 & Akçalı 14 & $(36.4258-35.9113)$ \\
\hline 8 & Madenli 8 & $(36.4633-35.9881)$ & 43 & Akçalı 15 & (36.4230 - 35.9109) \\
\hline 9 & Madenli 9 & (36.4547 - 35.9801) & 44 & Akçalı 16 & $(36.4192-35.9197)$ \\
\hline 10 & Madenli 10 & $(36.4573-35.9770)$ & 45 & Akçalı 17 & $(36.4149-35.9276)$ \\
\hline 11 & Üçgüllük 1 & $(36.4543-35.9683)$ & 46 & Akçalı 18 & $(36.4073-35.9264)$ \\
\hline 12 & Üçgüllük 2 & $(36.4468-35.9747)$ & 47 & Akçalı 19 & $(36.4107-35.9323)$ \\
\hline 13 & Üçgüllük 3 & $(36.4451-35.9731)$ & 48 & Akçalı 20 & $(36,4105-35,9379)$ \\
\hline 14 & Üçgüllük 4 & (36.4399 - 35.9758) & 49 & Gökmeydan 1 & $(36,4322-35,9345)$ \\
\hline 15 & Üçgüllük 5 & (36.4391 - 35.9705) & 50 & Gökmeydan 2 & $(36,4367-35,9268)$ \\
\hline 16 & Üçgüllük 6 & $(36.4375-35.9664)$ & 51 & Gökmeydan 3 & $(36,4369-35,9189)$ \\
\hline 17 & Üçgüllük 7 & $(36.4360-35.9697)$ & 52 & Gökmeydan 4 & $(36,4435-35,9214)$ \\
\hline 18 & Üçgüllük 8 & $(36.4349-35.9844)$ & 53 & Gökmeydan 5 & $(36,4350-35,9107)$ \\
\hline 19 & Üçgüllük 9 & $(36.4413-35.9822)$ & 54 & Çetellik 1 & $(36,4037-35,9313)$ \\
\hline 20 & Üçgüllük 10 & $(36.4377-35.9822)$ & 55 & Çetellik 2 & $(36,3945-35,9276)$ \\
\hline 21 & Üçgüllük 11 & $(36.4451-35.9567)$ & 56 & Çetellik 3 & $(36,3887-35,9287)$ \\
\hline 22 & Üçgüllük 12 & $(36.4559-35.9588)$ & 57 & Çetellik 4 & $(36,4029-35,9132)$ \\
\hline 23 & Üçgüllük 13 & $(36.4559-35.9603)$ & 58 & Çetellik 5 & $(36,4078-35,9051)$ \\
\hline 24 & Üçgüllük 14 & (36.4484 - 35.9679) & 59 & Çetellik 6 & $(36.4108-35.8982)$ \\
\hline 25 & Üçgüllük 15 & $(36.4330-35.9831)$ & 60 & Çetellik 7 & $(36.4104-35.8905)$ \\
\hline 26 & Üçgüllük 16 & $(36.4527-35.9868)$ & 61 & Çetellik 8 & $(36.4056-35.8844)$ \\
\hline 27 & Üçgüllük 17 & $(36.4316-35.9861)$ & 62 & Çetellik 9 & $(36.3921-35.8941)$ \\
\hline 28 & Üçgüllük 18 & $(36.4270-35.9859)$ & 63 & Çetellik 10 & $(36.3922-35.8749)$ \\
\hline 29 & Akçalı 1 & $(36.4586-35.9587)$ & 64 & Çetellik 11 & $(36.3816-35.8713)$ \\
\hline 30 & Akçalı 2 & $(36.4379-35.9461)$ & 65 & Çetellik 12 & $(36.3762-35.8631)$ \\
\hline 31 & Akçalı 3 & $(36.4215-35.9513)$ & 66 & Çetellik 13 & $(36.3732-35.8592)$ \\
\hline 32 & Akçalı 4 & $(36.4197-35.9482)$ & 67 & Çetellik 14 & $(36.4180-35.9062)$ \\
\hline 33 & Akçalı 5 & $(36.4229-35.9544)$ & 68 & Çetellik 15 & (36.4095 - 35.9149) \\
\hline 34 & Akçalı 6 & (36.4304 - 35.9658) & 69 & Çetellik 16 & $(36.4087-35.9216)$ \\
\hline 35 & Akçalı 7 & (36.4249 - 35.9719) & 70 & Çetellik 17 & $(36.4002-35.9004)$ \\
\hline
\end{tabular}

\section{BULGULAR ve TARTIŞMA}

\section{Toprakların bazı fiziksel ve kimyasal özellikleri}

Hatay ili Arsuz ilçesi maydanoz ekilen toprakların bazı fiziksel ve kimyasal özellikleri Çizelge 2'de verilmiştir. Çalışma alanı topraklarının pH'ları 7.65-8.42 aralığında, ortalama 8.07 olarak belirlenmiş ve toprak örneklerinin pH'ları tüm çalışma alanı boyunca hafif alkalin reaksiyonlu olduğu görülmüştür. Aynı bölgede çalışan Yeter ve Yalçın (2020) Hatay'ın Kırıkhan ilçesi tarım topraklarının $\mathrm{pH}$, kireç ve organik madde içeriklerini, Yalçın ve ark., (2018) Hatay Reyhanlı çayır-mera alanlarının beslenme durumlarını ve bunların bazı toprak özellikleri ile ilişkilerinin belirlenmesini amaçladıkları çalışmalar ile benzer sonuçlar ortaya koymuşlardır.

Çalışma alanı toplam tuz içeriği \%0.013-0.033 arasında değişirken, ortalama \%0.020 ve tüm alanın tuzsuz özellikte olduklarını bildirmişlerdir. Çalışma alanına yakın Amik ovası topraklarında çalışan Yalçın (2004), çalıştığı 
130 adet toprak örneğinin ikisi hariç tümünün tuzsuz sınıfında yer aldığını bildirmiştir.

Çalışma alanı topraklarının ortalama kil, kum ve silt içerikleri sırasıyla \%43.16, 19.09 ve 37.84 olarak bulunmuştur. Benzer bir çalışma Yalçın (2012) Amik ovasında tuzlulukla ilgili toprak özelliklerinin yersel ve zamansal değişiminin jeoistatistik yöntemlerle araştırılmasının amaçlandığı çalışmada toprakların ortalama kil, kum ve sil değerlerinin sırasıyla \%55.10, 18.46 ve 26.4 değerleri belirleyerek paralel sonuçlar ortaya koymuştur.

Araştırma alanı topraklarının kireç içerikleri \%0.62-28.04 arasında, ortalama \%14.69 olarak ve yaygın olarak orta ile çok kireçli topraklar olarak belirlenmiştir. Aynı bölgede yapılan çalışmada Yeter ve Yalçın (2020) Hatay ili Kırıkhan-Kumlu bölgesi topraklarının kireç içeriklerinin \%0.47-26.59 değerleri arasında bulmuşlardır.

Topraklarının organik madde içeriği \%1.68-4.09 olarak belirlenirken ortalama organik madde $\% 2.50$ bulunmuştur. Aynı bölgede yaptıkları çalışmada, Bilge ve Yalçın (2018) Hatay ili Kırıkhan-Reyhanlı bölgesi çayırmera topraklarının $\mathrm{pH}$, kireç ve organik madde içeriklerinin belirlenmesini amaçladıkları çalışma sonucunda toprakların organik madde içeriğini \% 0.295.52 değerleri arasında belirleyerek benzer sonuçlar ortaya koymuşlardır.

Çalışma alanı topraklarının katyon değişim kapasitesi (KDK) içeriklerine bakıldığında; KDK değerlerinin 13.09 ile $34.25 \mathrm{Cmol} / \mathrm{kg}$ arasında belirlenmiş ve ortalama 22.54 $\mathrm{Cmol} / \mathrm{kg}$ olarak bulunmuştur (Çizelge 2). Benzer olarak, Hatay ili Kırıkhan-Reyhanlı tarım topraklarının pH, kireç, organik madde ve katyon değişim kapasitesi (KDK) içeriklerinin belirlenmesi isimli çalışmada Yalçın (2020), toprakların KDK içeriklerini 16.89-42.10 Cmol/kg arasında belirlemiştir.

Çizelge 2. Hatay ili Arsuz ilçesi topraklarının bazı fiziksel ve kimyasal özellikleri

Table 2. Some physical and chemical properties of the soils of Arsuz district of Hatay province

\begin{tabular}{|c|c|c|c|c|c|c|c|c|c|}
\hline $\begin{array}{c}\text { Örnek } \\
\text { No }\end{array}$ & $\begin{array}{l}\mathrm{pH} \\
\text { Sat. }\end{array}$ & $\begin{array}{c}\text { Tuz } \\
\%\end{array}$ & $\begin{array}{l}\text { Kil } \\
\%\end{array}$ & $\begin{array}{c}\text { Kum } \\
\%\end{array}$ & $\begin{array}{l}\text { Silt } \\
\%\end{array}$ & $\begin{array}{l}\text { Bünye } \\
\text { Sınıfı }\end{array}$ & $\begin{array}{c}\text { Kireç } \\
\%\end{array}$ & $\begin{array}{c}\text { O.M. } \\
\%\end{array}$ & $\begin{array}{c}\mathrm{KDK} \\
\mathrm{Cmol} / \mathrm{kg}\end{array}$ \\
\hline 1 & 8.29 & 0.033 & 55.60 & 6.40 & 38.00 & $C$ & 8.88 & 3.52 & 22.33 \\
\hline 2 & 8.28 & 0.029 & 43.60 & 9.68 & 46.72 & $\mathrm{SiC}$ & 16.98 & 2.47 & 25.70 \\
\hline 3 & 8.42 & 0.017 & 43.60 & 9.68 & 46.72 & $\mathrm{SiC}$ & 19.63 & 2.45 & 20.78 \\
\hline 4 & 8.15 & 0.022 & 43.60 & 28.40 & 28.00 & C & 26.32 & 2.87 & 29.44 \\
\hline 5 & 8.12 & 0.017 & 39.60 & 36.40 & 24.00 & $\mathrm{CL}$ & 22.58 & 3.02 & 31.08 \\
\hline 6 & 8.19 & 0.023 & 44.32 & 9.12 & 46.56 & $\mathrm{SiC}$ & 15.26 & 2.76 & 22.96 \\
\hline 7 & 8.28 & 0.019 & 42.32 & 11.68 & 46.00 & $\mathrm{SiC}$ & 12.15 & 2.79 & 21.62 \\
\hline 8 & 8.26 & 0.020 & 47.60 & 14.40 & 38.00 & C & 10.59 & 2.54 & 25.88 \\
\hline 9 & 8.16 & 0.021 & 35.60 & 46.40 & 18.00 & SC & 2.65 & 2.51 & 25.05 \\
\hline 10 & 8.24 & 0.020 & 51.60 & 12.40 & 36.00 & C & 10.75 & 2.80 & 24.34 \\
\hline 11 & 8.31 & 0.019 & 18.88 & 51.12 & 30.00 & L & 5.45 & 1.70 & 13.09 \\
\hline 12 & 8.26 & 0.013 & 32.32 & 14.40 & 53.28 & $\mathrm{SiCL}$ & 17.76 & 3.08 & 16.60 \\
\hline 13 & 8.22 & 0.025 & 56.88 & 11.12 & 32.00 & C & 14.17 & 2.58 & 19.98 \\
\hline 14 & 8.02 & 0.020 & 50.88 & 8.40 & 40.72 & $\mathrm{SiC}$ & 12.15 & 3.87 & 21.32 \\
\hline 15 & 7.96 & 0.019 & 48.88 & 8.40 & 42.72 & $\mathrm{SiC}$ & 13.08 & 1.97 & 21.11 \\
\hline 16 & 7.81 & 0.025 & 44.88 & 10.40 & 44.72 & $\mathrm{SiC}$ & 20.09 & 2.51 & 19.41 \\
\hline 17 & 8.05 & 0.016 & 46.32 & 8.40 & 45.28 & $\mathrm{SiC}$ & 14.33 & 2.38 & 19.81 \\
\hline 18 & 8.13 & 0.017 & 45.60 & 8.40 & 46.00 & $\mathrm{SiC}$ & 21.18 & 2.46 & 20.45 \\
\hline 19 & 8.12 & 0.021 & 49.60 & 10.40 & 40.00 & $\mathrm{SiC}$ & 21.49 & 1.85 & 24.75 \\
\hline 20 & 8.18 & 0.015 & 51.60 & 6.40 & 42.00 & $\mathrm{SiC}$ & 19.47 & 2.08 & 22.70 \\
\hline 21 & 8.15 & 0.014 & 54.88 & 17.12 & 28.00 & C & 14.33 & 2.20 & 27.67 \\
\hline 22 & 8.12 & 0.014 & 60.32 & 3.68 & 36.00 & C & 12.93 & 2.52 & 20.91 \\
\hline 23 & 8.21 & 0.022 & 55.60 & 22.40 & 22.00 & C & 22.58 & 1.68 & 24.89 \\
\hline 24 & 8.08 & 0.015 & 46.32 & 29.68 & 24.00 & $C$ & 9.35 & 2.41 & 20.10 \\
\hline 25 & 8.22 & 0.023 & 47.60 & 11.12 & 41.28 & $\mathrm{SiC}$ & 16.98 & 2.17 & 18.52 \\
\hline 26 & 7.75 & 0.022 & 29.60 & 14.40 & 56.00 & $\mathrm{SiCL}$ & 5.92 & 2.10 & 16.42 \\
\hline 27 & 8.01 & 0.017 & 36.32 & 13.68 & 50.00 & $\mathrm{SiCL}$ & 21.65 & 2.53 & 18.19 \\
\hline 28 & 8.17 & 0.016 & 37.60 & 16.40 & 46.00 & $\mathrm{SiCL}$ & 28.04 & 2.42 & 18.63 \\
\hline 29 & 8.08 & 0.024 & 49.60 & 11.68 & 38.72 & C & 20.40 & 2.65 & 22.67 \\
\hline
\end{tabular}


Çizelge 2 (devamı). Hatay ili Arsuz ilçesi topraklarının bazı fiziksel ve kimyasal özellikleri

Table 2 (continued). Some physical and chemical properties of the soils of Arsuz district of Hatay province

\begin{tabular}{|c|c|c|c|c|c|c|c|c|c|}
\hline 30 & 8.16 & 0.018 & 50.32 & 8.40 & 41.28 & $\mathrm{SiC}$ & 27.26 & 2.23 & 21.36 \\
\hline 31 & 8.16 & 0.027 & 25.60 & 10.40 & 64.00 & SiL & 13.86 & 2.01 & 20.95 \\
\hline 32 & 8.17 & 0.022 & 33.60 & 30.40 & 36.00 & $C L$ & 10.59 & 1.89 & 18.55 \\
\hline 33 & 8.13 & 0.023 & 44.32 & 11.68 & 44.00 & $\mathrm{SiC}$ & 18.69 & 1.74 & 20.53 \\
\hline 34 & 7.89 & 0.015 & 34.32 & 19.68 & 46.00 & $\mathrm{SiCL}$ & 20.56 & 2.08 & 17.08 \\
\hline 35 & 7.91 & 0.014 & 37.60 & 24.40 & 38.00 & $\mathrm{CL}$ & 23.36 & 2.41 & 21.41 \\
\hline 36 & 8.13 & 0.022 & 39.60 & 12.40 & 48.00 & $\mathrm{SiCL}$ & 11.84 & 1.92 & 18.86 \\
\hline 37 & 8.25 & 0.018 & 36.32 & 23.68 & 40.00 & $\mathrm{CL}$ & 19.47 & 2.34 & 19.95 \\
\hline 38 & 8.10 & 0.018 & 43.60 & 11.68 & 44.72 & $\mathrm{SiC}$ & 14.02 & 2.38 & 23.09 \\
\hline 39 & 8.12 & 0.019 & 42.32 & 23.68 & 34.00 & $C$ & 13.71 & 2.41 & 21.92 \\
\hline 40 & 8.17 & 0.027 & 41.60 & 25.68 & 32.72 & $C$ & 14.80 & 2.37 & 20.13 \\
\hline 41 & 8.25 & 0.019 & 49.60 & 14.40 & 36.00 & $C$ & 20.25 & 2.85 & 24.90 \\
\hline 42 & 8.04 & 0.016 & 45.60 & 17.68 & 36.72 & $C$ & 18.07 & 1.82 & 19.97 \\
\hline 43 & 8.25 & 0.020 & 38.88 & 12.40 & 48.72 & $\mathrm{SiCL}$ & 16.98 & 1.85 & 18.96 \\
\hline 44 & 7.97 & 0.017 & 40.32 & 25.68 & 34.00 & $C$ & 19.63 & 3.64 & 21.61 \\
\hline 45 & 8.02 & 0.018 & 33.60 & 24.40 & 42.00 & $\mathrm{CL}$ & 13.55 & 2.28 & 17.87 \\
\hline 46 & 7.95 & 0.018 & 52.32 & 13.68 & 34.00 & $C$ & 13.24 & 2.52 & 21.22 \\
\hline 47 & 8.02 & 0.023 & 41.60 & 10.40 & 48.00 & $\mathrm{SiC}$ & 17.76 & 2.14 & 19.62 \\
\hline 48 & 8.03 & 0.015 & 40.32 & 20.96 & 38.72 & $C$ & 14.49 & 2.69 & 20.17 \\
\hline 49 & 8.08 & 0.021 & 42.32 & 13.68 & 44.00 & $\mathrm{SiC}$ & 10.44 & 2.86 & 23.18 \\
\hline 50 & 8.06 & 0.026 & 45.04 & 8.96 & 46.00 & $\mathrm{SiC}$ & 10.75 & 2.94 & 22.06 \\
\hline 51 & 8.11 & 0.018 & 48.88 & 22.40 & 28.72 & $C$ & 12.46 & 2.77 & 25.93 \\
\hline 52 & 8.05 & 0.014 & 35.60 & 46.40 & 18.00 & SC & 10.59 & 2.17 & 19.32 \\
\hline 53 & 8.08 & 0.017 & 52.88 & 23.12 & 24.00 & C & 10.12 & 2.70 & 30.49 \\
\hline 54 & 7.81 & 0.022 & 37.60 & 26.40 & 36.00 & $\mathrm{CL}$ & 10.90 & 2.38 & 20.57 \\
\hline 55 & 7.96 & 0.022 & 45.60 & 12.40 & 42.00 & $\mathrm{SiC}$ & 10.12 & 2.37 & 27.84 \\
\hline 56 & 7.70 & 0.020 & 37.60 & 16.40 & 46.00 & $\mathrm{SiCL}$ & 16.98 & 2.07 & 21.15 \\
\hline 57 & 8.14 & 0.022 & 47.60 & 13.68 & 38.72 & C & 10.12 & 2.20 & 24.06 \\
\hline 58 & 7.82 & 0.020 & 45.60 & 15.68 & 38.72 & C & 9.97 & 2.78 & 26.33 \\
\hline 59 & 8.09 & 0.016 & 43.60 & 17.68 & 38.72 & C & 17.91 & 2.49 & 20.42 \\
\hline 60 & 7.95 & 0.024 & 51.60 & 14.40 & 34.00 & $C$ & 13.24 & 3.21 & 27.38 \\
\hline 61 & 7.84 & 0.026 & 31.60 & 38.40 & 30.00 & $\mathrm{CL}$ & 3.74 & 1.69 & 24.57 \\
\hline 62 & 7.87 & 0.018 & 41.60 & 30.40 & 28.00 & $C$ & 0.93 & 3.20 & 31.56 \\
\hline 63 & 7.96 & 0.024 & 43.60 & 34.40 & 22.00 & $C$ & 0.62 & 2.68 & 34.25 \\
\hline 64 & 7.98 & 0.025 & 41.60 & 32.40 & 26.00 & C & 12.77 & 3.08 & 33.70 \\
\hline 65 & 7.95 & 0.029 & 37.60 & 28.40 & 34.00 & $\mathrm{CL}$ & 15.26 & 2.82 & 24.32 \\
\hline 66 & 7.95 & 0.015 & 38.88 & 27.12 & 34.00 & $\mathrm{CL}$ & 26.79 & 2.91 & 28.65 \\
\hline 67 & 7.97 & 0.021 & 55.60 & 10.40 & 34.00 & C & 15.11 & 2.18 & 23.67 \\
\hline 68 & 7.77 & 0.021 & 50.88 & 15.12 & 34.00 & $C$ & 16.04 & 2.55 & 25.01 \\
\hline 69 & 7.65 & 0.021 & 39.60 & 30.40 & 30.00 & $\mathrm{CL}$ & 12.15 & 2.68 & 21.02 \\
\hline 70 & 7.88 & 0.013 & 23.60 & 48.30 & 28.10 & L & 2.34 & 4.09 & 17.89 \\
\hline Min & 7.65 & 0.013 & 18.88 & 3.68 & 18.00 & & 0.62 & 1.68 & 13.09 \\
\hline Max & 8.42 & 0.033 & 60.32 & 51.12 & 64.00 & & 28.04 & 4.09 & 34.25 \\
\hline Ort.(Av.) & 8.07 & 0.020 & 43.16 & 19.09 & 37.84 & & 14.69 & 2.50 & 22.54 \\
\hline
\end{tabular}




\section{Toprak örneklerinin bazı besin elementi içerikleri}

\section{Azot}

Hatay Arsuz ilçesi maydanoz ekilen alanların bazı bitki besin maddeleri içeriklerine ait veriler Çizelge $3^{\prime}$ de özetlenmiştir. Çizelge 3 incelendiğinde topraklarının toplam azot miktarları en az \%0.03 iken, en fazla azot miktarı \%1.02, ortalama \%0.34 olarak belirlenmiştir. Alınan toprak örneklerinin toplam azot miktarları Kovancı (1969)'nın ifade ettiği sınır değerlerine göre sınıflandırıldığında, toprakların \%2.86'sı azotça çok düşük (<0.05), \%12.86'sı düşük (0.05-0.09), \%20.00'si orta (0.09-0.17), \%30.00'u yüksek (0.17-0.32) ve $\% 34.28^{\prime} i$ ise çok yüksek (>0.32) olarak belirlenmiştir (Çizelge 3). Toprakların yaklaşık \%84.28' inin azotça iyi durumda olması toprakların organik madde içeriklerine ek olarak, maydanoz ekilen bu alanlarda yoğun azotlu gübreleme yapılması ile de ilişkili olduğu söylenebilir. Ayrıca çalışma alanına yakın alanda çalışan Yalçın ve ark., (2018), Hatay çayır-mera topraklarının toplam azot içerikleri yönünden \%0.01-1.34 değerleri arasında olduğunu ve ortalama \%0.24 olarak belirlemişlerdir.

Çizelge 3. Hatay ili Arsuz ilçesi topraklarının N, P, K, Ca, Mg, Cu, Fe, Mn ve Zn içerikleri

Table 3. N, P, K, Ca, Mg, Cu, Fe, Mn and Zn concentrations of Arsuz District of Hatay Province

\begin{tabular}{|c|c|c|c|c|c|c|c|c|c|}
\hline \multirow{2}{*}{$\begin{array}{c}\text { Örnek } \\
\text { No }\end{array}$} & \multirow{2}{*}{$\begin{array}{l}\mathrm{N} \\
\%\end{array}$} & $P$ & $\mathrm{~K}$ & $\mathrm{Ca}$ & $\mathrm{Mg}$ & $\mathrm{Cu}$ & $\mathrm{Fe}$ & $\mathrm{Mn}$ & $\mathrm{Zn}$ \\
\hline & & \multicolumn{8}{|c|}{$\mathrm{mg} \mathrm{kg}^{-1}$} \\
\hline 1 & 0.30 & 0.77 & 449 & 4189 & 1187 & 1.94 & 4.30 & 2.88 & 0.34 \\
\hline 2 & 0.22 & 0.61 & 298 & 3833 & 1302 & 1.63 & 2.96 & 2.26 & 0.84 \\
\hline 3 & 0.20 & 0.26 & 159 & 3601 & 1127 & 1.74 & 4.00 & 2.42 & 0.24 \\
\hline 4 & 0.12 & 0.37 & 135 & 5169 & 672 & 1.34 & 3.68 & 3.96 & 1.18 \\
\hline 5 & 0.12 & 0.58 & 237 & 4869 & 937 & 1.31 & 1.65 & 3.09 & 1.50 \\
\hline 6 & 0.08 & 0.59 & 152 & 4105 & 987 & 1.65 & 2.85 & 3.21 & 1.00 \\
\hline 7 & 0.20 & 0.14 & 195 & 3743 & 982 & 1.60 & 3.63 & 3.05 & 0.15 \\
\hline 8 & 0.12 & 0.47 & 187 & 3998 & 999 & 1.71 & 2.73 & 3.25 & 0.32 \\
\hline 9 & 0.15 & 0.27 & 133 & 2478 & 1154 & 1.45 & 3.06 & 2.76 & 0.29 \\
\hline 10 & 0.07 & 0.35 & 179 & 3749 & 1180 & 1.30 & 2.50 & 1.97 & 0.35 \\
\hline 11 & 0.09 & 0.37 & 102 & 3156 & 619 & 0.92 & 3.25 & 1.42 & 0.24 \\
\hline 12 & 0.03 & 0.37 & 106 & 3544 & 798 & 1.41 & 4.15 & 2.64 & 0.28 \\
\hline 13 & 0.53 & 1.40 & 294 & 3664 & 1171 & 2.33 & 5.28 & 2.33 & 0.38 \\
\hline 14 & 0.30 & 1.70 & 200 & 3515 & 1146 & 2.75 & 4.84 & 1.49 & 0.75 \\
\hline 15 & 0.54 & 0.63 & 207 & 3797 & 1103 & 2.05 & 6.01 & 2.19 & 0.41 \\
\hline 16 & 0.28 & 1.42 & 297 & 3644 & 927 & 2.26 & 7.15 & 2.39 & 0.78 \\
\hline 17 & 0.31 & 0.41 & 186 & 3826 & 821 & 1.61 & 4.97 & 2.32 & 0.33 \\
\hline 18 & 0.20 & 1.82 & 179 & 3368 & 1212 & 2.64 & 7.42 & 2.00 & 0.99 \\
\hline 19 & 0.45 & 0.26 & 207 & 3647 & 1006 & 2.00 & 4.05 & 2.01 & 0.32 \\
\hline 20 & 0.27 & 0.99 & 138 & 3784 & 1009 & 1.84 & 6.35 & 1.38 & 0.21 \\
\hline 21 & 0.65 & 0.47 & 155 & 3770 & 310 & 2.14 & 4.72 & 2.56 & 0.51 \\
\hline 22 & 0.50 & 0.93 & 230 & 3643 & 1046 & 2.40 & 7.67 & 1.89 & 0.88 \\
\hline 23 & 0.14 & 0.81 & 230 & 2655 & 1693 & 0.65 & 2.54 & 1.67 & 0.35 \\
\hline 24 & 0.07 & 0.96 & 298 & 3405 & 1075 & 2.22 & 4.36 & 3.70 & 0.61 \\
\hline 25 & 0.20 & 1.15 & 180 & 3545 & 969 & 2.41 & 4.70 & 2.61 & 0.52 \\
\hline 26 & 0.14 & 1.32 & 209 & 3333 & 923 & 2.08 & 5.03 & 5.00 & 0.42 \\
\hline 27 & 0.30 & 0.77 & 192 & 3615 & 807 & 2.35 & 3.86 & 2.65 & 0.61 \\
\hline 28 & 0.21 & 1.17 & 193 & 3599 & 851 & 2.04 & 3.42 & 5.90 & 0.58 \\
\hline 29 & 0.58 & 0.70 & 327 & 4113 & 999 & 2.17 & 5.23 & 3.49 & 0.27 \\
\hline 30 & 0.31 & 0.43 & 269 & 3796 & 986 & 2.42 & 6.07 & 2.18 & 0.39 \\
\hline 31 & 0.18 & 1.38 & 235 & 3676 & 1085 & 1.53 & 4.08 & 2.56 & 0.54 \\
\hline 32 & 0.15 & 0.43 & 141 & 3480 & 981 & 2.01 & 4.47 & 2.40 & 0.35 \\
\hline 33 & 0.27 & 0.58 & 164 & 3519 & 1208 & 2.14 & 6.39 & 4.33 & 0.22 \\
\hline 34 & 0.12 & 1.24 & 169 & 3996 & 555 & 1.42 & 4.79 & 3.37 & 1.21 \\
\hline 35 & 0.14 & 0.41 & 182 & 4777 & 355 & 1.50 & 5.17 & 3.99 & 0.48 \\
\hline 36 & 0.06 & 0.31 & 207 & 4260 & 586 & 2.75 & 9.43 & 11.57 & 0.39 \\
\hline 37 & 0.07 & 0.96 & 170 & 3686 & 911 & 3.58 & 6.84 & 18.63 & 0.80 \\
\hline 38 & 0.04 & 0.44 & 136 & 3907 & 1129 & 4.22 & 10.27 & 19.15 & 0.36 \\
\hline 39 & 0.13 & 0.46 & 373 & 3932 & 870 & 2.73 & 6.48 & 16.12 & 0.54 \\
\hline
\end{tabular}


Çizelge 3 (devamı). Hatay ili Arsuz ilçesi topraklarının N, P, K, Ca, Mg, $\mathrm{Cu}, \mathrm{Fe}, \mathrm{Mn}$ ve $\mathrm{Zn}$ içerikleri Table 3 (continued). $\mathrm{N}, \mathrm{P}, \mathrm{K}, \mathrm{Ca}, \mathrm{Mg}, \mathrm{Cu}, \mathrm{Fe}, \mathrm{Mn}$ and $\mathrm{Zn}$ concentrations of Arsuz District of Hatay Province

\begin{tabular}{|c|c|c|c|c|c|c|c|c|c|}
\hline 40 & 0.08 & 0.45 & 523 & 3734 & 907 & 3.16 & 9.04 & 19.64 & 0.69 \\
\hline 41 & 0.24 & 0.62 & 315 & 3706 & 1161 & 3.48 & 11.83 & 19.87 & 1.45 \\
\hline 42 & 0.15 & 0.79 & 212 & 3573 & 1223 & 3.03 & 12.97 & 19.95 & 1.69 \\
\hline 43 & 0.95 & 0.30 & 124 & 3794 & 941 & 3.28 & 14.63 & 11.24 & 0.35 \\
\hline 44 & 0.76 & 1.20 & 427 & 3952 & 811 & 3.40 & 9.51 & 20.13 & 1.09 \\
\hline 45 & 0.89 & 0.83 & 113 & 3655 & 873 & 3.72 & 9.59 & 17.91 & 1.17 \\
\hline 46 & 0.69 & 0.98 & 258 & 3591 & 1250 & 3.77 & 11.17 & 17.28 & 0.53 \\
\hline 47 & 1.02 & 0.70 & 132 & 3832 & 975 & 2.73 & 7.65 & 13.80 & 0.75 \\
\hline 48 & 0.82 & 0.97 & 162 & 3671 & 984 & 3.41 & 7.83 & 19.89 & 0.67 \\
\hline 49 & 0.36 & 0.20 & 286 & 4067 & 911 & 3.91 & 8.23 & 17.40 & 0.49 \\
\hline 50 & 0.23 & 0.30 & 310 & 4227 & 1018 & 3.68 & 10.17 & 16.57 & 0.49 \\
\hline 51 & 1.01 & 0.32 & 202 & 4113 & 772 & 2.24 & 10.44 & 20.16 & 0.51 \\
\hline 52 & 0.67 & 0.33 & 114 & 3548 & 564 & 2.26 & 6.05 & 19.09 & 0.28 \\
\hline 53 & 0.94 & 0.25 & 307 & 5137 & 754 & 1.23 & 9.20 & 18.69 & 0.75 \\
\hline 54 & 0.82 & 0.71 & 197 & 4104 & 706 & 3.38 & 9.44 & 22.47 & 1.68 \\
\hline 55 & 0.42 & 0.49 & 308 & 4048 & 815 & 4.77 & 18.72 & 17.10 & 0.57 \\
\hline 56 & 0.30 & 1.54 & 441 & 4156 & 613 & 4.15 & 14.64 & 22.07 & 1.61 \\
\hline 57 & 0.56 & 0.49 & 235 & 3761 & 1158 & 3.72 & 12.57 & 15.48 & 0.50 \\
\hline 58 & 0.29 & 0.35 & 229 & 4042 & 1015 & 4.59 & 17.35 & 21.71 & 0.66 \\
\hline 59 & 0.41 & 0.26 & 191 & 4036 & 876 & 3.05 & 16.43 & 19.51 & 0.26 \\
\hline 60 & 0.27 & 0.14 & 204 & 4161 & 1141 & 3.36 & 10.90 & 17.91 & 0.71 \\
\hline 61 & 0.74 & 0.73 & 216 & 3436 & 856 & 2.20 & 6.04 & 19.93 & 1.45 \\
\hline 62 & 0.53 & 0.65 & 150 & 2933 & 1194 & 1.58 & 7.48 & 20.02 & 0.92 \\
\hline 63 & 0.59 & 0.28 & 206 & 3248 & 1399 & 2.11 & 5.69 & 21.17 & 1.71 \\
\hline 64 & 0.45 & 0.52 & 172 & 5294 & 812 & 1.66 & 6.75 & 21.94 & 1.27 \\
\hline 65 & 0.14 & 1.18 & 367 & 4165 & 773 & 1.89 & 5.22 & 17.31 & 1.10 \\
\hline 66 & 0.07 & 0.27 & 208 & 5472 & 473 & 1.02 & 3.35 & 5.13 & 0.60 \\
\hline 67 & 0.16 & 0.26 & 228 & 4433 & 865 & 3.02 & 11.54 & 5.73 & 0.16 \\
\hline 68 & 0.07 & 0.47 & 212 & 4547 & 787 & 2.00 & 5.12 & 9.91 & 0.47 \\
\hline 69 & 0.25 & 0.31 & 264 & 4386 & 594 & 2.62 & 12.15 & 7.34 & 0.72 \\
\hline 70 & 0.12 & 0.98 & 161 & 3007 & 611 & 2.22 & 7.26 & 9.97 & 1.38 \\
\hline Min & 0.03 & 0.14 & 102 & 2478 & 310 & 0.65 & 1.65 & 1.38 & 0.15 \\
\hline Max & 1.02 & 1.82 & 523 & 5472 & 1693 & 4.77 & 18.72 & 22.47 & 1.71 \\
\hline Ort.(Av.) & 0.34 & 0.67 & 223 & 3860 & 936 & 2.41 & 7.13 & 9.84 & 0.68 \\
\hline
\end{tabular}

\section{Fosfor}

Arsuz bölgesi topraklarının alınabilir fosfor içerikleri en düşük $0.14 \mathrm{mg} \mathrm{kg}^{-1}$ iken, en yüksek $1.82 \mathrm{mg} \mathrm{kg}^{-1}$ olarak, ortalama $0.67 \mathrm{mg} \mathrm{kg}^{-1}$ olarak belirlenmiştir. Hatay ili Arsuz ilçesi toprakları Ülgen ve Yurtsever (1995)' in bildirdiği sınır değerlerine göre değerlendirildiğinde toprakların tamamının fosfor içeriği çok düşük (<3 mg kg$\left.{ }^{1}\right)$ olduğu bulunmuştur (Çizelge 3 ). Kireç ve $\mathrm{pH}$ içeriklerinin yüksek olan kireçli alkalin topraklarda bitkiye alınabilir fosforun kalsiyum bileşikleri oluşturmak suretiyle fikse olduğu ve bu topraklarda bitkiye alınabilir fosforu temsil eden Olsen fosforunun çok düşük olması bilinen bir durumdur (Çimrin, 1996; Kacar ve Katkat, 1997; Çimrin, 2020)

\section{Potasyum}

Arsuz maydanoz ekim alanları topraklarının değişebilir potasyum içeriği en düşük $102 \mathrm{mg} \mathrm{kg}^{-1}$ iken, en yüksek potasyum içeriği $523 \mathrm{mg} \mathrm{kg}^{-1}$, ortalama $223 \mathrm{mg} \mathrm{kg}^{-1}$ olarak belirlenmiştir. Toprak örneklerinin değişebilir potasyum içerikleri Pizer (1967)'in verdiği sınır değerlere göre sınıflandırıldığında, \%47.15'i düşük (100-200 mg kg $\left.{ }^{1}\right)$, \%25.71'i orta $\left(200-250 \mathrm{mg} \mathrm{kg}^{-1}\right), \%$ 17.14'ü yüksek (250-320 mg kg-1) ve \%10.00'u çok yüksek (>320 mg kg-1) düzeyde potasyum içerdiği belirlenmiştir (Çizelge 3 ). Aynı bölge topraklarında yapılan bir çalışmada, Uludağ ve Ağca (2019) Arsuz ovası topraklarında potasyum fraksiyonlarının uzaysal dağılımının jeoistatistik yöntemlerle belirlenmesinin amaçlandığı çalışmada toprakların değişebilir potasyum içeriğini $70.0-777.5 \mathrm{mg}$ $\mathrm{kg}^{-1}$ değerleri arasında olduğunu belirleyerek toprakların değişebilir potasyum içeriği yönünden benzer sonuçlar ortaya koymuşlardır. 


\section{Kalsiyum}

Toprakların kalsiyum içeriği örneklerde en düşük 2478 $\mathrm{mg} \mathrm{kg}^{-1}$ iken, en yüksek kalsiyum $5472 \mathrm{mg} \mathrm{kg}^{-1}$, ortalama kalsiyum içeriği $3860 \mathrm{mg} \mathrm{kg}^{-1}$ olarak bulunmuştur. Toprak örneklerinin kalsiyum içeriği Summer ve Miller (1996)'a göre sınıflandırılmıştır ve toprakların kalsiyum içeriği \% $15.71^{\prime} i$ yeterli $\left(1150-3500 \mathrm{mg} \mathrm{kg}^{-1}\right)$ ve $\% 84.29^{\prime} \mathrm{u}$ ise fazla (3500-10000 mg kg-1) seviyede kalsiyum içerdiği belirlenmiştir (Çizelge 3). Yakın bir bölgede yapılan çalışmada, Bozgeyik ve Çimrin (2020) Gaziantep' in bir kısım antepfıstığı ağaçlarının yaprak ve toprak örnekleri ile besin elementi ve beslenme durumunun belirlenmesini amaçladıkları çalışmada toprakların değişebilir Ca değerlerinin 5018-8718 $\mathrm{mg} \mathrm{kg}^{-1}$ arasında değiştiğini belirlenirken toprakların değişebilir Ca içeriği yönünden benzer sonuçlar ortaya konmuştur.

\section{Magnezyum}

Toprakların magnezyum içeriği örneklerde en düşük 310 $\mathrm{mg} \mathrm{kg}{ }^{-1}$ iken, en yüksek magnezyum $1693 \mathrm{mg} \mathrm{kg}^{-1}$, ortalama magnezyum içeriği $935.85 \mathrm{mg} \mathrm{kg}^{-1}$ olarak bulunmuştur. Toprak örneklerinin magnezyum içeriği Summer ve Miller (1996)'a göre sınıflandırıldığında toprakların magnezyum içeriğinin \%4.28'i yeterli (160$\left.480 \mathrm{mg} \mathrm{kg}^{-1}\right), \% 94.29^{\prime} \mathrm{u}$ fazla $\left(480-1500 \mathrm{mg} \mathrm{kg}^{-1}\right)$ ve \%1.43'ü ise çok fazla $\left(>1500 \mathrm{mg} \mathrm{kg}^{-1}\right)$ seviyede olduğu belirlenmiştir (Çizelge 3). Yakın bir bölgede yapılan çalışmada Bozgeyik ve Çimrin (2020) Gaziantep yöresi antepfıstığı ağaçlarının yaprak ve toprak örnekleri ile beslenme durumunun belirlenmesini amaçladıkları çalışmada değişebilir Mg yönünden toprakların \%90'ının fazla olduğunu belirterek benzer sonuçlar ortaya koymuşlardır.

\section{Bakır}

Çalışma alanının toprak bakır içeriği örneklerde en düşük $0.65 \mathrm{mg} \mathrm{kg}^{-1}$ iken, en yüksek $4.77 \mathrm{mg} \mathrm{kg}^{-1}$, ortalama 2.41 $\mathrm{mg} \mathrm{kg^{-1 }}$ olarak belirlenmiştir. Toprak örnekleri için Lindsay ve Norwell (1978) bakır için bildirdiği sınır değerleri ile karşılaştırıldığında örneklerin tamamının bakır miktarı açısından yeterli düzeyde $\left(>0.2 \mathrm{mg} \mathrm{kg}^{-1}\right)$ olduğu görülmüştür (Çizelge 3 ). Aynı bölgede yapılan çalışmada, Yalçın ve ark. (2018) Hatay ili Kırıkhan Reyhanlı bölgesi çayır-mera topraklarının besin elementi durumları ve bazı toprak özellikleri ile ilişkilerinin belirlenmesinin amaçlandığı çalışmada toprakların alınabilir $\mathrm{Cu}$ değerlerini $0.26-7.48 \mathrm{mg} \mathrm{kg}^{-1}$ değerleri arasında belirleyerek benzer veriler ortaya koymuşlardır.

\section{Demir}

Çalışma alanının topraklarının demir içerikleri en az 1.65 $\mathrm{mg} \mathrm{kg}^{-1}$ iken, en yüksek demir içeriği $18.72 \mathrm{mg} \mathrm{kg}^{-1}$ olarak ortalama demir içeriği $7.13 \mathrm{mg} \mathrm{kg}^{-1}$ olarak bulunmuştur. Toprak demir içerikleri Lindsay ve Norwell (1978)'in sınır değerlerine göre sınıflandırıldığında örneklerin \% $1.43^{\prime}$ ünde demir noksanlığı $\left(<2.5 \mathrm{mg} \mathrm{kg}^{-1}\right), \% 27.14^{\prime}$ ü yeterli (2.5-4.5 $\left.\mathrm{mg} \mathrm{kg}^{-1}\right)$ ve \% 71.43'ü ise demir yönünden fazla (>4.5 mg kg${ }^{-1}$ ) durumda belirlenmiştir (Çizelge 3). Aynı bölge topraklarında yapılan bir çalışmada Yalçın ve Çimrin (2019a) Hatay ili Kırıkhan-Reyhanlı arası çayırmera topraklarının molibden içeriğinin belirlenmesi ve toprak içerisindeki bazı ağır metaller ile ilişkilerinin saptanmasını amaçladıkları çalışmada toprakların alınabilir $\mathrm{Fe}$ içeriğinin $4.00-61.00 \mathrm{mg} \mathrm{kg}^{-1}$ değerleri arasında olduğunu ortaya koyarak benzer sonuçlar bildirmişlerdir.

\section{Mangan}

Çalışma alanının topraklarının alınabilir mangan içerikleri örneklerde en düşük $1.38 \mathrm{mg} \mathrm{kg}^{-1}$ iken, en yüksek 22.47 $\mathrm{mg} \mathrm{kg}{ }^{-1}$, ortalama mangan içeriği $9.84 \mathrm{mg} \mathrm{kg}^{-1}$ olarak bulunmuştur. Çalışma alanı topraklarının hepsinin alınabilir mangan içerikleri FAO (1990)'nun verdiği sınır değerlerine göre sınıflandırıldığında toprakların $\% 45.72$ 'si çok düşük (<4 mg kg-1), \%14.28'i düşük (4-14 $\mathrm{mg} \mathrm{kg}{ }^{-1}$ ) ve $\% 40.00$ '। ise yeterli (14-50 $\mathrm{mg} \mathrm{kg}^{-1}$ ) düzeyde bulunmuştur (Çizelge 3). Yakın bir bölgede yapılan çalışmada, Keleş Uzel ve Çimrin (2020) Gaziantep deki bazı zeytin bahçelerinin yaprak ve toprak örnekleri ile beslenme durumunun belirlenmesini amaçladıkları çalışmada alınabilir mangan içerikleri yönünden toprakların yeterli düzeyde olduğunu ve alınabilir mangan değerlerini $3.71-13.37 \mathrm{mg} \mathrm{kg}^{-1}$ olarak belirleyerek bezer sonuçlar ortaya koymuşlardır.

\section{Çinko}

Hatay ili Arsuz ilçesi topraklarının alınabilir çinko içerikleri en düşük $0.15 \mathrm{mg} \mathrm{kg}^{-1}$ iken, en yüksek $1.71 \mathrm{mg}$ $\mathrm{kg}^{-1}$, ortalama çinko içeriği $0.68 \mathrm{mg} \mathrm{kg}^{-1}$ olarak bulunmuştur. Hatay ili Arsuz ilçesi toprakları alınabilir çinko içerikleri Viets ve Lindsay (1973)'e göre \% 62.86'sında noksanlık $\left(<0.7 \mathrm{mg} \mathrm{kg}^{-1}\right), \% 15.72$ 'sinde kritik (0.7-1 $\left.\mathrm{mg} \mathrm{kg}^{-1}\right)$ ve \% 21.42'sinde ise yeterli $\left(>1 \mathrm{mg} \mathrm{kg}^{-1}\right.$ ) düzeyde olduğu belirlenmiştir (Çizelge 3 ). Benzer şekilde ülkemizin birçok kireçli alkalin karakterli topraklarda yaygın olarak çinko noksanlığı görülmektedir. Van yöresinde Karaçal ve Çimrin (1997), Hatay ili KırıkhanReyhanlı bölgesinde Yalçın ve ark., (2018), ManisaAkhisar yöresinde Bayram ve ark., (2019) Şanlıurfa-Suruç bölgesi topraklarında Öztürkmen ve ark., (2020) toprakların yarayışı $\mathrm{Zn}$ içeriği açısından benzer sonuçları ortaya koymuşlardır. 


\section{Çalışma alanı bazı toprakların özellikleri ile alınabilir besin maddeleri arasındaki ilişkiler}

Hatay ili Arsuz maydanoz ekimi yapılan toprakların özellikleri ile bitki tarafından alınabilir bazı besin maddeleri arasındaki ilişkiler Çizelge 4'de verilmiştir. Çizelge 4' e bakıldığında görüleceği gibi toprakların fosfor içeriği ile KDK $\left(r:-0.34^{* * *}\right)$ negatif önemli ilişki belirlenirken, fosfor ile silt $\left(r: 0.27^{*}\right)$ içeriği arasında ise pozitif önemli ilişkiler saptanmıştır. Karaduman ve Çimrin (2016) Gaziantep yöresi tarım topraklarının besin elementi durumları ve bunların bazı toprak özellikleri ile ilişkilerinin belirlenmesi isimli çalışmada, toprakların alınabilir fosfor içeriği ile KDK içeriği arasında negatif önemli ilişki ortaya koyarak benzer sonuçları bildirmişlerdir. Toprakların değişebilir potasyum içerikleri ile tuz ( $r$ : $\left.0.44^{* * *}\right)$ ve kil ( $r$ : $\left.0.26^{*}\right)$ içeriği arasında pozitif önemli ilişkiler belirlenmiştir. Bayram (2019) Gediz havzası tütün tarımı yapılan toprakların bazı fiziksel-kimyasal özellikleri ile besin elementi içerikleri arasındaki ilişkilerin belirlenmesini amaçladığı çalışma sonucunda, değişebilir $\mathrm{K}$ ile tuz ve kil içerikleri ile pozitif önemli ilişki belirlemişlerdir. Ayrıca toprakların değişebilir kalsiyum ile kireç ( $\left.r: 0.36^{* * *}\right)$ ve KDK içeriği ( $r$ : $0.40^{* * *}$ ) arasında ise pozitif önemli ilişkiler saptanmıştır. Benzer şekilde Yalçın ve ark., (2018) Hatay ili KırıkhanReyhanlı bölgesi çayır-mera topraklarının besin elementi durumları ve bazı toprak özellikleri ile ilişkilerinin belirlenmesinin amaçlandığı çalışmada, toprakların değişebilir kalsiyum ile kireç ve KDK içerikleri arasında pozitif önemli ilişkiler belirlemişlerdir. Toprakların değişebilir magnezyum ile kum ( $r$ :-0.32***) arasında negatif, magnezyum ile $\mathrm{pH}\left(\mathrm{r}: 0.33^{* * *}\right)$, tuz $\left(\mathrm{r}: 0.34^{* * *}\right)$ ve kil ( $\left.r: 0.40^{* * *}\right)$ arasında ise pozitif önemli ilişkiler açığa çıkmıştır. Bayram ve ark., (2019) Manisa-Akhisar yöresinde yoğun tarımı yapılan biber bahçelerinin beslenme durumlarının belirlenmesi amacıyla yaptıkları çalışmada, toprakların değişebilir Mg içeriği ile kum içerikleri arasında negatif, kil içerikleri arasında ise pozitif önemli ilişkiler belirlemişlerdir. Toprakların alınabilir bakır ile $\mathrm{pH}$ içeriği $\left(r:-0.27^{*}\right)$ ve kum içeriği arasında negatif önemli ( $r$ :-0.24*) ilişki belirlenmiştir. Benzer şekilde Yalçın ve Çimrin (2019b) Şanlıurfa-Siverek'te yaygın toprak gruplarının besin elementi durumları ve bunların bazı toprak özellikleri ile ilişkilerinin belirlenmesi isimli çalışmada, toprakların bakır ile kum içeriği arasında önemli negatif ilişki belirlemişlerdir. Benzer şekilde Van yöresi tarım topraklarının besin elementi durumları ve bunların bazı toprak özellikleri ile ilişkileri isimli çalışmalarında Çimrin ve Boysan, (2016) toprakların bakır ile kum içeriği arasında negatif önemli ilişki belirlemişlerdir. Toprakların alınabilir demir ile $\mathrm{pH}$ içeriği ( $r$ : $\left.-0.36^{* * *}\right)$ ve kum içeriği $\left(r:-0.26^{* * *}\right)$ arasında negatif önemli ilişki saptanmıştır. Sönmez ve ark., (2018) Bolu Abant İzzet Baysal Üniversitesi araştırma alanları topraklarının bazı fiziksel ve kimyasal özelliklerinin belirlenmesi amacıyla yaptıkları çalışma sonucunda, toprakların alınabilir demir içeriği ile $\mathrm{pH}$ ve kum içeriği arasında negatif ilişki belirlemişlerdir. Ayrıca toprakların mangan ile $\mathrm{pH}\left(\mathrm{r}:-0.37^{* *}\right)$ ve kireç içeriği $\left(r:-0.29^{*}\right)$ arasında negatif, kum ( $r$ : $\left.0.27^{*}\right)$ ve KDK içeriği ( $r: 0.26^{*}$ ) arasında ise pozitif önemli ilişkiler belirlenmiştir.

Farklı bir bölgede yapılan çalışmada, Atmaca ve Nalbant (2020) Giresun ili Şebinkarahisar ilçesinde farklı topoğrafyalarda oluşmuş toprakların tarımsal özelliklerinin belirlenmesinin amaçlandığı çalışmada, toprakların alınabilir $\mathrm{Mn}$ içeriği ile $\mathrm{pH}$ ve kireç içeriği arasında negatif önemli ilişki belirleyerek benzer sonuçlar ortay koymuşlardır. Toprakların alınabilir Zn ile $\mathrm{pH}$ içeriği $\left(\mathrm{r}\right.$ : $\left.-0.41^{* * *}\right)$ arasında negatif ilişki belirlenir iken alınabilir $Z n$ ile kum ( $r: 0.33^{* * *}$ ) ve KDK içeriği ( $r$ : $0.27^{*}$ ) arasında ise pozitif ilişki saptanmıştır. Farklı bir bölgede yapılan çalışmada, Atmaca ve Nalbant (2020) Giresun ili Şebinkarahisar ilçesinde farklı topoğrafyalarda oluşmuş toprakların tarımsal özelliklerinin belirlenmesinin amaçlandığı çalışmada, toprakların alınabilir Zn içeriği ile kum içeriği arasında pozitif önemli ilişki belirleyerek benzer sonuçlar ortay koymuşlardır.

Sonuç olarak, Hatay ili Arsuz ilçesi maydanoz ekilen alanların topraklarının bazı bitki besin maddeleri miktarları belirlenerek, bunların bazı toprak karakteristikleri arasındaki ilişkileri belirlenmek suretiyle bu alanların verimlilik durumlarının ortaya çıkarılmasına çalışıımıştır. Arsuz ilçesi topraklarının pH' ları genelde bitki yetiştirime açısından problemsizi hafif bazik reaksiyonlu, tuzluluk açısından bakıldığında ise topakların tuzsuz sınıfına girmesi nedeniyle bitki yetiştirme için bir engel olmadığını göstermektedir.

Arsuz ilçesi topraklarının yedi değişik bünye sınıfına sahip olduğu ve toprakların genelinde ise \% 67.14'ünün kil ile siltli kil içerikli olduğu söylenebilir. Çalışma alanı toprakların kireç yönünden \% 87.15 'inde orta kireç ile çok kireçli olduğu ve toprakların \% 84.19'unun orta ile iyi oranda organik madde içeriğine sahip olduğu görülmüştür.

Hatay ili Arsuz ilçesi maydanoz alanları topraklarının verimlilik durumları değerlendirildiğinde şimdilik azot açısından yeterli düzeyde olmasına rağmen, toprakların bitkiye alınabilir fosfor ve çinko açısından noksanlığın olduğu ve gübreleme ile mutlaka desteklenmesi gerektiği ortaya çıkmaktadır. 
Çizelge 4. Hatay ili Arsuz ilçesi topraklarının besin elementleri ile bazı toprak özellikleri arasındaki korelasyon katsayıları ( $r$ )

Table 4. Correlation coefficients between the nutrients of Arsuz district of Hatay province and some soil properties ( $r$ )

\begin{tabular}{|c|c|c|c|c|c|c|c|c|c|c|c|c|c|c|c|c|}
\hline & $\mathrm{pH}$ & Tuz & Kil & Kum & Silt & Kireç & OM & KDK & $\mathrm{N}$ & $P$ & $\mathrm{~K}$ & $\mathrm{Ca}$ & $\mathrm{Mg}$ & $\mathrm{Cu}$ & $\mathrm{Fe}$ & $\mathrm{Mn}$ \\
\hline Tuz & 0.23 & & & & & & & & & & & & & & & \\
\hline Kil & 0.17 & 0.09 & & & & & & & & & & & & & & \\
\hline Kum & -0.20 & -0.15 & $-0.58^{* * *}$ & & & & & & & & & & & & & \\
\hline Silt & 0.10 & 0.10 & -0.18 & $-0.69^{* * *}$ & & & & & & & & & & & & \\
\hline Kireç & 0.19 & -0.20 & 0.19 & $-0.37^{* * *}$ & $0.29^{*}$ & & & & & & & & & & & \\
\hline OM & -0.10 & -0.02 & 0.09 & 0.09 & -0.19 & -0.15 & & & & & & & & & & \\
\hline KDK & -0.10 & 0.19 & $0.38^{* * *}$ & 0.13 & $-0.49 * * *$ & -0.11 & $0.30^{*}$ & & & & & & & & & \\
\hline $\mathrm{N}$ & -0.16 & -0.03 & 0.15 & 0.01 & -0.15 & -0.17 & -0.03 & 0.13 & & & & & & & & \\
\hline$P$ & -0.20 & 0.04 & -0.08 & -0.17 & $0.27^{*}$ & 0.14 & 0.05 & $-0.34^{* * *}$ & -0.02 & & & & & & & \\
\hline K & -0.14 & $0.44^{* * *}$ & $0.26^{*}$ & -0.15 & -0.04 & 0.04 & 0.20 & 0.10 & -0.04 & 0.19 & & & & & & \\
\hline $\mathrm{Ca}$ & -0.19 & 0.07 & 0.17 & -0.10 & -0.02 & $0.36^{* * *}$ & 0.22 & $0.40^{* * *}$ & 0.01 & $-0.27^{*}$ & 0.19 & & & & & \\
\hline $\mathrm{Mg}$ & $0.33^{* * *}$ & $0.34^{* * *}$ & $0.40^{* * *}$ & $-0.32^{* * *}$ & 0.03 & -0.11 & -0.03 & 0.15 & -0.03 & 0.13 & 0.08 & $-0.48^{* * *}$ & & & & \\
\hline $\mathrm{Cu}$ & $-0.27^{*}$ & 0.04 & 0.10 & $-0.24^{*}$ & 0.20 & -0.10 & 0.02 & -0.12 & $0.26^{*}$ & 0.07 & $0.27^{*}$ & -0.01 & 0.04 & & & \\
\hline $\mathrm{Fe}$ & $-0.36^{* * *}$ & -0.04 & 0.11 & -0.13 & 0.06 & -0.13 & -0.03 & 0.02 & $0.34^{* * *}$ & -0.10 & 0.22 & 0.13 & -0.06 & $0.81^{* * *}$ & & \\
\hline $\mathrm{Mn}$ & $-0.37^{* * *}$ & 0.05 & -0.11 & $0.27^{*}$ & -0.23 & $-0.29^{*}$ & 0.13 & $0.26^{*}$ & $0.43^{* * *}$ & -0.14 & 0.23 & 0.15 & -0.07 & $0.63^{* * *}$ & $0.67^{* * *}$ & \\
\hline $\mathrm{Zn}$ & $-0.41^{* * *}$ & 0.04 & -0.21 & $0.33^{* * *}$ & -0.21 & -0.06 & 0.22 & $0.27^{*}$ & 0.14 & $0.31^{* * *}$ & 0.16 & 0.12 & -0.07 & 0.15 & 0.15 & $0.45^{* * *}$ \\
\hline
\end{tabular}

*. ***; ile gösterilen korelasyon değerleri sırasılyla $P<0.05$ ve $P<0.001$ düzeyinde önemlidir. 
Toprakların toplam azot içeriği ile $\mathrm{Cu}$, Fe ve $\mathrm{Mn}$ içeriği; alınabilir fosfor içeriği ile alınabilir Zn içeriği; değişebilir potasyum içeriği ile alınabilir $\mathrm{Cu}$ içeriği; alınabilir $\mathrm{Cu}$ içeriği ile alınabilir Fe ve Mn içeriği; alınabilir demir içeriği ile alınabilir $\mathrm{Mn}$ içeriği ve alınabilir $\mathrm{Mn}$ içeriği ile alınabilir Zn içeriği arasında önemli pozitif ilişki belirlenmiştir, Toprakların alınabilir fosfor ile değişebilir Ca içeriği; değişebilir Ca içeriği ile değişebilir Mg içeriği arasında ise önemli negatif ilişkiler saptanmıştır.

Ayrıca toprakların alınabilir fosfor ile KDK içerikleri, alınabilir Mg ile kum içerikleri, alınabilir bakır ve demir ile $\mathrm{pH}$ ve kum içerikleri, alınabilir mangan ile $\mathrm{pH}$ ve kireç içerikleri ve alınabilir çinko ile $\mathrm{pH}$ değerleri arasında negatif önemli ilişkiler bulunmuştur. Toprakların alınabilir fosfor ile silt içerikleri, değişebilir potasyum ile tuz ve kil içerikleri, kalsiyum ile kireç ve KDK değerleri, alınabilir magnezyum ile $\mathrm{pH}$, tuz ve kil içerikleri, alınabilir mangan ve çinko ile kum ve KDK değerleri arasında ise pozitif önemli ilişkiler belirlenmiştir.

\section{ÖZET}

Amaç: Hatay iline bağlı Arsuz ilçesi topraklarının bazı makro ve mikro besin elementi içeriklerinin belirlenmesi ve bunların bazı toprak özellikleri ile olan ilişkilerini ortaya koyarak, bölge topraklarının verimlilik durumlarının değerlendirilmesi amaçlanmıştır.

Yöntem ve Bulgular: Çalışmada Hatay-Arsuz ilçesi topraklarını temsil edecek şekilde $0-30 \mathrm{~cm}$ derinlikten ve 70 farklı noktadan olmak üzere toplamda 70 adet yüzey toprak örneği alınmıştır. Araştırma sonuçlarına göre; toprakların toplam $\mathrm{N}$ içerikleri \% 0.03 ile \% 1.02 arasında, yarayışı $\mathrm{P} 0.14$ ile $1.82 \mathrm{mg} \mathrm{kg}^{-1}$; değişebilir K 102 ile 523 $\mathrm{mg} \mathrm{kg}^{-1}$; değişebilir Ca 2478-5472 $\mathrm{mg} \mathrm{kg}^{-1}$; değişebilir Mg 310 ile $1693 \mathrm{mg} \mathrm{kg}^{-1}$; alınabilir Cu 0.65 ile $4.77 \mathrm{mg} \mathrm{kg}^{-1}$; Fe 1.65 ile $18.72 \mathrm{mg} \mathrm{kg}^{-1}$; Mn 1.38 ile $22.47 \mathrm{mg} \mathrm{kg}^{-1}$ ve $\mathrm{Zn}$ 0.15 ile $1.71 \mathrm{mg} \mathrm{kg}^{-1}$ arasında belirlenmiştir. Arsuz ilçesi toprakları \% 2.86'sı N çok düşük, \% 12.86'sı düşük, \% 20.00 'si orta, \% 30.00'u yüksek, \% 34.28'i ise çok yüksek durumdadır.

Genel Yorum: Çalışma alanı toprakların tamamında fosfor içeriği bakımından çok düşük düzeyde fosfor belirlenmiştir. Toprakların değişebilir potasyum içeriği yönünden bakıldığında \% 47.15'i düşük, \% 25.71'i orta, \% 17.14 'ü yüksek ve \% 10.00'u ise çok yüksek düzeyde belirlenmiştir. Toprakların büyük bir çoğunluğunda alınabilir $\mathrm{Zn}$ ve $\mathrm{Mn}$ yönünden noksanlık belirlenirken, toplam $\mathrm{N}$, alınabilir $\mathrm{Ca}, \mathrm{Mg}, \mathrm{Cu}, \mathrm{Fe}$ ve içerikleri bakımından ise herhangi bir noksanlığa rastlanmamıştır. Toprakların alınabilir P ile KDK içerikleri, alınabilir Mg ile kum içerikleri, alınabilir $\mathrm{Cu}$ ve $\mathrm{Fe}$ ile $\mathrm{pH}$ ve kum içerikleri, alınabilir $\mathrm{Mn}$ ile $\mathrm{pH}$ ve kireç içerikleri ve alınabilir $\mathrm{Zn}$ ile
$\mathrm{pH}$ değerleri arasında negatif önemli ilişkiler bulunmuştur. Toprakların alınabilir $\mathrm{P}$ ile silt içerikleri, değişebilir $\mathrm{K}$ ile tuz ve kil içerikleri, Ca ile kireç ve KDK değerleri, alınabilir $\mathrm{Mg}$ ile $\mathrm{pH}$, tuz ve kil içerikleri, alınabilir $\mathrm{Mn}$ ve $\mathrm{Zn}$ ile kum ve KDK değerleri arasında ise pozitif önemli ilişkiler belirlenmiştir.

Çalışmanın Önemi ve Etkisi: Hatay ili Arsuz ilçesi topraklarının verimlilik durumları incelendiğinde toprakların alınabilir $\mathrm{P}, \mathrm{Zn}$ ve $\mathrm{Mn}$ noksanlıklarının belirlendiği ve gübreleme ile mutlaka bu besin elementlerince desteklenmesi gerektiği ortaya çıkmaktadır.

Anahtar Kelimeler: Arsuz ilçesi, toprak özellikleri, verimlilik.

\section{ÇIKAR ÇATIŞMA BEYANI}

Yazar(lar) çalışma konusunda çıkar çatışmasının olmadığını beyan eder.

\section{ARAŞTIRMACILARIN KATKI ORANI BEYANI}

Yazarlar çalışmaya eşit oranda katkı sağlamış olduklarını beyan eder.

\section{KAYNAKLAR}

Anonymous (1992) Soil survey staff, procedures for collecting soil samples and methods of analysis for soil survey. Soil Surv. Invest. Rep. I. U.S. Gov. Print. Office, Washington D.C. USA.

Atmaca B, Nalbant H (2020) Giresun ili Şebinkarahisar ilçesinde farklı topoğrafyalarda oluşmuş toprakların tarımsal özellikleri. Toprak Bil. ve Bitki Bes. Derg. 8(2): 145-156.

Bayram SE (2019) Gediz havzası tütün tarımı yapılan toprakların bazı fiziksel-kimyasal özellikleri ile besin elementi içerikleri arasındaki ilişkiler. TURJAF 7(11): 1917-1923.

Bayram SE, Elmacı ÖL, Özden N (2019) Manisa-Akhisar yöresi biber (capsicum annuum) plantasyonlarının beslenme durumları. JOTAF 16 (2): 144-155.

Bilge MS, Yalçın M (2018) Hatay ili Kırıkhan-Reyhanlı bölgesi çayır - mera topraklarının $\mathrm{pH}$, kireç ve organik madde içeriklerinin belirlenmesi. Imcofe V. Inter. Multidisciplinary Cong. of Eur. July 24-26, 2018 Barcelona-Spain, 156-163.

Bouyoucos GJ (1952) A Recalibration of the hydrometer for making mechanical analysis of soil. Agronomy Journ. 43(9): 434-438. 
Bozgeyik T, Çimrin KM (2020) Gaziantep ili Nizip ilçesi antepfıstığı ağaçlarının yaprak ve toprak örnekleri ile beslenme durumunun belirlenmesi. KSÜ Tar ve Doğa Derg. 23(3): 722-732.

Bremner JM, Mulvaney CS (1982) Nitrogen-Total. in: page, a.l., Miller, R.H., Keeney, d.r (eds.), Methods of soil analysis, Part 2. Chemical and Microbiological Properties. 2 nd ed., Agronomy 9: 595-624.

Çimrin KM (1996) Yüzüncü Yıl Üniversitesi kampüs alanı toprak profillerinde fosfor fraksiyonlarının dağılımı. Y.Y.Üniv. Fen Bil Enst, 80 s. (Basılmamış Doktora Tezi).

Çimrin KM (2018) Gaziantep ili kiraz (Prunus avium L.) bahçelerinin beslenme durumları. Adyutayam Derg. 6(2): 8-17.

Çimrin KM (2020) Relationship between some soil characteristics and contribution on available phosphorus of inorganic phosphorus fractions in calcareous soils. MKU. Tar. Bil. Derg. 25(2): 138-144. DOI: $10.37908 /$ mkutbd. 702342

Çimrin K M, Boysan S (2006) Van yöresi tarım topraklarının besin elementi durumları ve bunların bazı toprak özellikleri ile ilişkileri. YYU. Zir. Fak. Tar. Bil. Derg. 16(2): 105-111.

Düzgüneş O, Kesici T, Kavuncu O, Gürbüz F (1987) Araştırma deneme metotları (istatistik metotları-II). Ankara Üni. Zir. Fak. Yay: 1021. Ankara. 381s.

Doğan A, Erdal i (2018) Burdur ili tahıl yetiştirilen toprakların verimlilik durumlarının belirlenmesi. Toprak Bil. ve Bitki Bes. Derg. 6(1): 39-45.

Eren A (2019) Kızıltepe yöresinde buğday tarımı yapılan toprakların bazı verimlilik durumlarının belirlenmesi. Gaziosmanpaşa Bil. Araş. Derg. (GBAD) 8(1): 1-9.

Horneck DA, Hart JM, Topper K, Koepsell B (1989) Methods of soil analysis used in the soil testing laboratory at Oregon State University. P 1-21. Agr. Exp. Sta. Oregon, USA.

FAO (1990) Micronutrients assessment at the country level. An International Study (M. Sillanpaa, ed.) FAO Soil Bulletin 63. Published by FAO. Roma, Italy. 128 pp.

Kacar B, Katkat V (1997) Tarımda fosfor. Bursa Ticaret Borsası yayınları No: 5, Uludağ Üniv. Basım Evi, Bursa, ISBN: 975-512-217-6.

Karaçal i, Çimrin KM (1997) Yüzüncü yıl üniversitesi kampüs alanı toprak profillerinin $\mathrm{Zn}$ durumu ve bu elementin bazı toprak özellikleri ile ilişkileri. I. Ulusal Çinko Kong., 12-16 Mayıs, Eskişehir, 123-130.

Karaduman A, Çimrin KM (2016) Gaziantep yöresi tarım topraklarının besin elementi durumları ve bunların bazı toprak özellikleri ile ilişkileri. KSÜ Doğa Bil. Derg. 19(2): 117-129.

Keleş Uzel N, Çimrin KM (2020) Gaziantep ili Nizip ilçesi zeytin bahçelerinin yaprak ve toprak örnekleri ile beslenme durumunun belirlenmesi. KSÜ Tar. Doğa Derg. 23(4): 1039-1053.

Kovancı i (1969) İzmir bölgesi tarla topraklarında nitrifikasyon durumu ve bunların bazı toprak özelliği ile olan ilişkisi üzerinde araştırmalar. Ege Üni Zir Fak Bitki Bes kürsüsü (basılmamış doçentlik tezi). İzmir.

Lindsay W L, Norwell WA (1978) Development of a DTPA test for zinc, iron, manganese and copper. J. Soil Sci. Am. 42: 421-428.

Nelson RE (1982) Carbonate and gypsum. Methods of soil analysis part 2. Chemical and microbiological properties second edition. Agronomy. No: 9 Part 2. Edition pp: 191-197.

Nelson DW, Sommers LE (1982) Organic matter. Methods of soil analysis part 2. Chemical and microbiological properties second edition. Agronomy. No: 9 Part 2. Edition pp: 574-579.

Olsen SR, Sommers EL (1982) Phosphorus availability indices. Phosphorus soluble in sodium bicarbonate. (Eds: A.L. Page, R.H. Miller, D.R. Keeney), Methods of Soils Analysis, Part II., Chemical and Microbiological Properties p. 404-430.

Öztürkmen AR, Ramazanoğlu E, Çiçek ic (2020) Şanlıurfa ili Suruç ilçesi topraklarının bazı özellikleri ve bitki besin elementi kapsamlarının belirlenmesi. BEÜ Fen Bil. Derg. 9 (4): 1807-1815.

Pizer NH (1967) Some advisory aspects soil potassium and magnesium. Tech. Bult. N. 14-184.

Rhoades JD (1982) Cation exchange capacity. Methods of Soil Analysis Part 2. Chemical and Microbiological Properties Second Edition. Agronamy No: 9 Part 2. Edition P: 149-157.

Uludağ B, Ağca N (2019) Arsuz ovası topraklarında potasyum fraksiyonlarının uzaysal dağılımının jeoistatistik yöntemlerle belirlenmesi. Mustafa Kemal Üniv. Tar. Bil Derg. 24(3): 295-307.

Ülgen N, Yurtsever N (1995) Türkiye gübre ve gübreleme rehberi (4. Baskı). T.C. Başbakanlık Köy Hiz Genel Müd Toprak ve Gübre Araş Ensti Müd Yay., Genel Yayın No: 209, Teknik Yayınlar No: T.66, 230 s.

Sönmez F, Gülser F, Karaca S, Gökkaya TH (2018) Bolu abant izzet baysal üniversitesi araştırma alanları topraklarının bazı fiziksel ve kimyasal özelliklerinin belirlenmesi. Uluslararası Tarım ve Yaban Hay Bil Derg. (UTYHBD) 4(1): 68-78.

Sumner ME, Miller WP (1996) Cation exchange capacity and exchange cations. In: Sparks, D.L. (Ed), Methods of Soil Analysis. Part 3, Chemical Methods: pp. 12011229. ASA and SSSA, Madison, WI, SSSA Book Series No: 5. 
Viets FG, Lindsay WL (1973) Testing soils for zinc. Copper. Managanese and iron. Soil Soc. of Amer. Inc. Madison Wisconcin USA. 153-172.

Yalçın M (2004) Amik Ovası topraklarının temel kimyasal ve fiziksel özelliklerinin belirlenmesi. Mustafa Kemal Üni. Fen Bil. Ens. Yüksek Lisans Tezi, $118 \mathrm{~s}$.

Yalçın M (2012) Amik Ovasında tuzlulukla ilgili toprak özelliklerinin yersel ve zamansal değişiminin jeoistatistik yöntemlerle araştırılması. Mustafa Kemal Üni. Fen Bil. Ens. Doktora Tezi. 146 s.

Yalçın M (2020) Hatay ili Kırıkhan-Reyhanlı tarım topraklarının $\mathrm{pH}$, kireç, organik madde ve KDK içeriklerinin belirlenmesi. ISPEC 2020: 4(3): 623-634.

Yalçın M, Çimrin KM (2019a) Determination of molybdenum contents and relation of some heavy metals in the soil of meadow-pasture terraces between Kırıkhan-Reyhanlı. TURJAF 7(1): 13-21.
Yalçın M, Çimrin KM (2019b) Şanlıurfa-Siverek'te yaygın toprak gruplarının besin elementi durumları ve bunların bazı toprak özellikleri ile ilişkileri. KSÜ Tar. Doğa Derg. 22(1): 1-13.

Yalçın M, Çimrin KM, Tutuş Y (2018) Hatay ili Kırıkhan Reyhanlı bölgesi çayır-mera topraklarının besin elementi durumları ve bazı toprak özellikleri ile ilişkileri. KSÜ Tar. Doğa Derg. 21(3): 385-396.

Yeter K, Yalçın M (2020) Hatay ili Kırıkhan-Kumlu bölgesi topraklarının $\mathrm{pH}$, kireç ve organik madde içeriklerinin belirlenmesi. ISPEC 2020: 4(2): 285-293. 